\title{
Comparison of Cytotoxicity between Ethyl Acetate and Ethanol Extract of White Turmeric (Kaempferia rotunda) Rhizome Extract Against HeLa Cervical Cancer Cell Activity
}

\author{
Surya Dwira' ${ }^{1}$ Ariska TP², Fadilah Fadilah ${ }^{1,3, *}$, Norma Nur Azizah ${ }^{3}$, Linda Erlina ${ }^{1}$
}

Surya Dwira' ${ }^{1}$, Ariska TP², Fadilah Fadilah $^{1,3, *}$, Norma Nur Azizah ${ }^{3}$, Linda Erlina'

'Department of Medical Chemistry, Faculty of Medicine, University of Indonesia, INDONESIA.

${ }^{2}$ Medical Student, Faculty of Medicine University of Indonesia, INDONESIA. ${ }^{3}$ Drug Development Research Cluster, Indonesia Medical Education and Research Institute (IMERI), Faculty of Medicine, University of Indonesia, Jalan Salemba Raya 6 Jakarta 10430, INDONESIA.

\section{Correspondence}

\section{Fadilah Fadilah}

Department of Medical Chemistry, Faculty of Medicine, University of Indonesia; Drug Development Research Cluster, Indonesia Medical Education and Research Institute (IMERI), Faculty of Medicine, University of Indonesia, Jalan Salemba Raya 6 Jakarta 10430, INDONESIA.

E-mail: fadilah81@gmail.com

History

- Submission Date: 25-05-2020;

- Review completed: 04-07-2020;

- Accepted Date: 06-07-2020.

DOI : 10.5530/pj.2020.12.178

Article Available online

http://www.phcogj.com/v12/i6

Copyright

(C) 2020 Phcogj.Com. This is an openaccess article distributed under the terms of the Creative Commons Attribution 4.0 International license.

\begin{abstract}
Aim: The aim of this study is to compare between ethanol and ethyl acetate rhizome extract of K.rotunda against HeLa cervical cancer cell in vitro. Material and Methods: Methods used in this research are test the chemical compound of extracts using Thin Layer Chromatography (TLC) and phytochemical screening test, also cytotoxicity test using MTT assay. Result: Ethyl acetate extract contains flavonoid, alkaloid, tannin, and triterpenoid, while ethanol extract have flavonoid, triterpenoid, and alkaloid. In addition, ethanol extract has strong cytotoxic activity $\left(I C_{50}=16,939 \mu \mathrm{g} / \mathrm{ml}\right)$ while ethyl acetate extract has moderate cytotoxic activity $\left(I C_{50}=\right.$ $127,9 \mu \mathrm{g} / \mathrm{ml})$. Each of extracts showed significant results $(p \leq 0,05)$ although when compared between concentrations there are several concentrations that are not significant and also small coefficient of determinant values caused by various confounding factors. Conclusion: The ethanol extract of K.rotunda rhizome extract has the higher cytotoxicity activity compared to ethyl acetate extract of K.rotunda rhizome extract against HeLa cervical cancer cell.

Key words: Anti cervical cancer, HeLa, In vitro, Kaempferia rotunda.
\end{abstract}

\section{INTRODUCTION}

Cervical cancer is the fifth highest cancer in the world. This cancer is the most common cancer in developing countries and also one of the top ten cancers in developed countries. Based of research conducted by Ministry of Health in Indonesia on 2013, cervical cancer has the largest prevalence of cancer in Indonesia with $0,8 \%$, followed by breast cancer. The annual number of new patients with cervical cancer is estimated to reach $90-100$ casese per 100.000 population and there are 40.000 new cases each year. ${ }^{1-3}$

There are several studies using plant extract in order to find the alternative treatment of cervical cancer, one of which is Kaempferia rotunda rhizome extract. There are 2 types of turmeric plants, namely yellow turmeric (Curcuma domestica) and white turmeric (Kaempferia rotunda). White turmeric in Chinese pharmacology is said to have properties that can stop bleeding and increase appetite. This plant is antineoplastic (damages the formation of ribosomes in cancer cells or inhibits the growth of cancer cells). The parts used are rhizomes and leaves. ${ }^{4}$

Pinostrobin is a kind of flavanone. It is the major compound that can be isolated from chloroform extract of Kaempferia rotunda. Herbal containing flavonoids have been widely used around the world. Epidemiological studies showed data that high dietary intake of flavonoids from fruits and vegetables could be associated with a low of prevalence cancer in human. Many studies showed that flavonoids may inhibit various stages such as cancer initiation, promotion, and progression. ${ }^{5}$
This plant extract contains various compounds that are cytotoxic to several cancer lines including HeLa cell as a part of cervical cancer line. The result of previous studies is that the chloroform extract of K.rotunda has higher cytotoxic activity compared with methanol and hexane extracts against HeLa cell. ${ }^{6}$

Although K.rotunda has been tested in various researches, but K.rotunda hasn't been tested yet using all types of solvents such as ethyl acetate and ethanol. Types of solvent could extract different compounds so the cytotoxicity activity should be different. Based on the previous research, the ethanol extract of this rhizome has a greater total phenolic, curcumin, and antioxidant activity than ethyl acetate extract. ${ }^{7,8}$

Therefore, we decided to conduct a research using ethyl acetate and ethanol extract of K.rotunda rhizome against HeLa cell in vitro. In this study, we compare cytotoxicity activity and phytochemical analysis of these extract.

\section{MATERIALS AND METHODS}

There are three experiment conducted in this study which are Thin-Layer Chromatography (TLC), phytochemical screening, and MTT Assay. TLC dan phytochemical screening are used for analyze compounds contained in both extracts while MTT Assay is used for measure the cytotoxic activity.

K.rotunda rhizomes were obtained from Bogor, Indonesia. The rhizomes were ground in the grinding machine and dried. Then, the rhizomes were seperated into two Erlenmeyer flasks to maceration process. The first Erlenmeyer flask was added by ethanol $96 \%$ while the second Erlenmeyer flask was

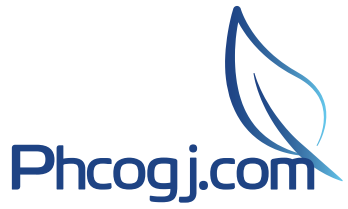

Cite this article: Dwira S, Ariska TP, Fadilah F, Azizah NN, Erlina L. Comparison of Cytotoxicity between Ethyl Acetate and Ethanol Extract of White Turmeric (Kaempferia rotunda) Rhizome Extract Against HeLa Cervical Cancer Cell Activity. Pharmacogn J. 2020;12(6):1297-302. 
added by ethyl acetate. Both Erlenmeyer flasks were covered by plastic and rubber. Maceration process took 48 hours until the extracts were obtained from these Erlenmeyer flasks. Both extracts were put into the evaporator in $60^{\circ} \mathrm{C}$ so that only the solutes were remained.

TLC was conducted by dissolving extracts with ethanol then dropping them using capillary to the plate which had a width of $1 \mathrm{~cm}$. TLC plat was marked with the initial line where the extracts were given and the end line. After that, the plate was inserted into the camber containing methanol and chloroform with a ratio of 5:1. If the liquid had reached the upper limit of the plate, then spots produced from that process were identified under UV light. The value of Retention factor $\left(\mathrm{R}_{\mathrm{f}}\right)$ can be assessed in the following equation:

$R=\frac{\text { Distance traveled by sample (initial line to spot) }}{\text { Distance traveled by solvent in the chamber (initial line to end line) }}$

Phytochemical screening were conducted to test seven compounds which are flavonoid, alkaloid, tannin, triterpenoid, steroid, glycosides, and saponin. All seven test were conducted according to the standard protocol.

HeLa cell was obtained and prepared from Department of Anatomical Pathology, Faculty of Medicine in Universitas Indonesia. The cell was incubated in $37^{\circ} \mathrm{C}$ and carbon dioxide $5 \%$ for one week. After that, the cultured cell was counted using haemocytometer by entering trypan blue $90 \mu \mathrm{L}$ into cell suspension $10 \mu \mathrm{L}$. Then, cell was examined under the microscope and measured with the following equation:

total cell $($ cell $/ \mathrm{ml})=\mathrm{P} \times(\mathrm{N} / 4) \times 10000$

Note:

$\mathrm{P}=$ dilution factor

$\mathrm{N}=$ Number of cell from 4 chamber

We used complete medium to grow the cell and extract dilution. The complete medium $500 \mathrm{ml}$ was made by combining Fetal Bovine Serum (FBS) 10\% $50 \mathrm{ml}$, penicilin-streptomycin $5 \mathrm{ml}$, Dulbecco's Modified Eagle Medium (DMEM). The complete medium was filtered by milipore. Complete medium is added to well plate 96 with HeLa cell then was incubated to conduct the cell culture process until $50 \%$ confluence in 48 hours.

The $10 \mathrm{ml}$ extracts were put into sentrifuge tube, added by Dimethyl Sulfoxide (DMSO) $1 \mathrm{ml}$, and mixed. Next, the mixtures were added by complete medium and mixed again until homogen. The final mixtures were diluted using serial dilution into eight concentration which are 6,25 ppm, 12,5 ppm, 25 ppm, 50 ppm, 100 ppm, 200 ppm, 400 ppm, and $800 \mathrm{ppm}$.

The plate was removed from incubator. Then, the medium was discarded from the well so what remain was only the cell. Each well was marked to separate the test groups, negative control, and positive control groups. $100 \mu \mathrm{L}$ of extract was put into the test groups, cisplatin was put into positive control groups, and $100 \mu \mathrm{L}$ of medium was put into negative control group. The plate was incubated for 48 hours.

After incubation, MTT reagent $5 \mathrm{mg} / \mathrm{ml}$ was added to each well then diluted 10 times using complete medium. Next, The plate was incubated for $3-4$ hour at $37^{\circ} \mathrm{C}$. The medium was discarded and the crystals formazan was formed in the form of purple color, showing the living cell. After that, the plate was put into the ELISA-reader to measure the absorbance or optical density (OD) using UV with the wavelength of $595 \mathrm{~nm}$. The results were collected to find the percentage of cell inhibiton with the following equation:

Cell inhibition $\%=\frac{O D \text { of negative control }-O D \text { of extract }}{O D \text { of negative control }} \times 100 \%$
The value of $\mathrm{IC}_{50}$ could be found using a graph with logarithm of extract concentration on the horizontal axis and the percentage of cell inhibiton on the vertical axis. $\mathrm{IC}_{50}$ shows the concentration of extract when there is $50 \%$ cell inhibition. The measurement of $\mathrm{IC}_{50}$ could be held using regression linear equation from the graph.

Finally, All data were processed and analyzed using SPSS 23. There were two groups, divided according to the extract. Each of groups was processed using normality test and comparative test. The normality test was conducted using Shapiro-Wilk because the number of samples are below 50. After that, we conducted unpaired numerical comparative test with groups more than two and post-hoc test according to the previous comparative analysis. We used one way ANOVA and Tamhane for posthoc test if the data was homogen or kruskal-walis and Mann-Whitney for post-hoc test if the data was heterogen. Data was statistically significant if the $\mathrm{p}$ value $<0,05$.

\section{RESULTS AND DISCUSSION}

\section{Thin-layer chromatography (TLC)}

In this study, the volume ratio solvent of methanol with chloroform was 5:1. The results of TLC are stated in Retention Factor $\left(\mathrm{R}_{\mathrm{f}}\right)$. The result are shown in Table 1 .

Ethanol extract produced seven spots. Meanwhile, ethyl acetate extract produced nine spot. This indicated that the ethyl acetate extract had more compounds than ethanol extract. The greater the $\mathrm{Rf}$ value the higher polar compounds, and vice versa. However, there are several factors affecting the result of TLC such as solvent used for sample extraction, solvent used for chamber, humidity, temperature, size of chamber, and plate thickness. ${ }^{9-11}$

\section{Phytochemical screening}

Ethanol extract of K.rotunda rhizome contained three compounds and ethyl acetate extract contained four compounds. Types of compounds from both extracts are described in Table 2 .

Based on previous research, there were several differences in phytochemical results both in ethanol extract and ethyl acetate extracts. Using the Salkowaski and Keller-Kilani testsn,it was stated that the ethyl acetate extract contained steroid. In another study, it was stated that the ethanol extract had saponin but didn't have alkaloid. This may be related to different extraction process ${ }^{12,13}$

\section{IC50 results of $K$.rotunda extract}

Absorbance or Optical Density (OD) value of negative control were $2.372,2.358$ and 2.346. From these values, its average value was 2.359 . The cisplatin was as positive control in this experiment. The optical density or absorbance of cisplatin are mentioned in Table 3.

$\mathrm{IC}_{50}$ was obtained from linear regression equation which describes the relationship between the percentage of cell inhibition and logarithm of extract concentration. By plotting log concentration of cisplatin vs OD average, it produced to an equation $y=25.83 \mathrm{x}+47.33$. If $\mathrm{y}$ was replaced by the number 50 , then the $\mathrm{x}$ value will be obtained 1.268 . So, $\mathrm{IC}_{50}$ of cisplatin was 1.268 .

The same method was also used to look for both $\mathrm{IC}_{50}$ of ethanol extract and $\mathrm{IC}_{50}$ of ethyl acetate extract. The optical density of ethanol extract and ethyl acetate extract were shown in Table 4 and 5.

The linier regression of ethanol extract was $y=19,454 x+26,093$, by replacing y with 50 , it yielded $\mathrm{IC}_{50}$, that was 16.939 .

The linier regresion of ethyl acetate extract was $y=32,805 x-19,113$. By replacing y with 50 , it yielded $\mathrm{IC}_{50}$, that was 127.9. Turmeric plants (include Kaempferia rotunda) are very rich in chemical ingredients such as tannins, curcumin, starch, sugar, essential oils, resin, saponins, 


\section{Table 1: Rf of Kaemferia rotunda.}

\begin{tabular}{|c|c|c|c|c|c|c|c|c|c|}
\hline \multirow{2}{*}{ Extract } & \multicolumn{9}{|c|}{ Rf value } \\
\hline & 1 & 2 & 3 & 4 & 5 & 6 & 7 & 8 & 9 \\
\hline ethanol & 0.222 & 0.319 & 0.444 & 0.514 & 0.681 & 0.801 & 0.944 & - & - \\
\hline ethyl acetate & 0.167 & 0.236 & 0.292 & 0.444 & 0.528 & 0.639 & 0.722 & 0.833 & 0.944 \\
\hline
\end{tabular}

Table 2: Phytochemical Screening of K.rotunda.

\begin{tabular}{ccc}
\hline Types of Compound & Ethyl acetate extract & Ethanol extract \\
\hline Saponin & - & - \\
Flavonoid & + & + \\
Triterpenoid & + & - \\
Steroid & - & + \\
Alkaloid & + & - \\
Tannin & + & - \\
Glycoside & - & - \\
\hline
\end{tabular}

Table 3: Optical Density (OD) of Cisplatin.

\begin{tabular}{ccccc}
\hline Concentration & OD average & Deviation & \% Inhibition & IC 50 \\
\hline 2 & 0,895 & 1,126 & 62,074 & \\
4 & 0,897 & 1,196 & 61,975 & \\
8 & 0,909 & 1,245 & 61,481 & 1.268 \\
16 & 0,667 & 1,014 & 71,711 & \\
32 & 0,092 & 0,052 & 96,086 & \\
\hline
\end{tabular}

Table 4: Optical Density (OD) of Ethanol Extract of K.rotunda.

\begin{tabular}{ccccc}
\hline Concentration & OD average & Deviation & \% Inhibition & IC 50 \\
\hline 6,25 & 0,882 & 1,213 & 62,611 & \\
12,5 & 1,866 & 0,39 & 20,885 & \\
25 & 2,021 & 0,264 & 14,328 & \\
50 & 0,269 & 0,133 & 88,583 & 16.939 \\
100 & 0,066 & 0,002 & 97,202 & \\
200 & 0,474 & 0,406 & 79,921 & \\
400 & 1,154 & 0,947 & 51,067 & \\
800 & 0,425 & 0,055 & 81,984 & \\
\hline
\end{tabular}

Table 5: Optical Density (OD) of Ethyl Acetate Extract of K.rotunda.

\begin{tabular}{ccccc}
\hline Concentration & OD average & Deviation & \% Inhibition & IC 50 \\
\hline 6,25 & 1,532 & 1,24 & 35,071 & \\
12,5 & 1,988 & 0,12 & 15,713 & \\
25 & 1,738 & 0,488 & 26,325 & 127.9 \\
50 & 2,106 & 0,225 & 10,725 & \\
100 & 1,821 & 0,32 & 22,82 & 41,218 \\
200 & 1,387 & 0,367 & 83,694 & \\
400 & 0,385 & 0,08 & 96,905 & \\
800 & 0,073 & 0,001 & & \\
\hline
\end{tabular}

flavonoids and toxic proteins that can inhibit the proliferation of cancer cells ${ }^{5}$. Curcumin and flavonoids function as antioxidants that can fight free radicals causing cancer $^{8}$. This antioxidant believed to have a function to prevent deoxyribonucleic acid (DNA) from gene damage. Gene damage is one of the factors that trigger cancer. ${ }^{14}$

According to the results of MTT Assay on HeLa cell, ethanol extract of K.rotunda rhizome has less $\mathrm{IC}_{50}$ value than ethyl acetate extract. It shows that ethanol extract has higher cytotoxic activity than ethyl acetate extract. Based on the classification of cytotoxicity according to $\mathrm{IC}_{50}$ value, ethanol extract has strong cytotoxic activity $(<50 \mathrm{ppm})$ while ethyl acetate extract has moderate cytotoxic activity (101-250 ppm). Moreover, ethanol extract of K.rotunda rhizome has stronger cytoxicity than other K.rotunda extracts based on previous research such as chloroform extract (62,358 ppm), ethanol extract (109,12 ppm), and hexane extract $(203,065)$.There are possibilities about another compounds contributing to cytotoxic activity which are not tested in this study. Previous studies explain that the ethanol extract has higher total phenolic, curcumin, and antioxidant activity than ethyl acetate extract of K.rotunda. ${ }^{4,6}$

However, there is an issue about coeficient of determination $\left(\mathrm{r}^{2}\right)$ obtained from this experiment. Both extracts have low $r^{2}(0,5783$ and $0,2134)$. These mean that both have several confounding factors other than independent variable that affect dependent factor. One of the example is solvent cytotoxicity because there was a research explains the potential cytotoxixity caused by solvent. The other factor is types of medium. The number of glucose in a medium could affect the absorbance of MTT Assay. The more glucose in the medium, the higher the absorbance. Another factors that could affect the result are culture 
time and MTT incubation time. The ideal time for cell culture is 72 96 hours while in this experiment only 48 hour. The absorbance will increase if MTT incubation time is longer, until at some point where the absorbance remains stable. ${ }^{15-18}$

Based on normality test, ethyl acetate extract datas were homogen while ethanol extract datas were heterogen. This means ethyl acetat extract datas were analyzed with oneway ANOVA while ethanol extract datas were analyzed with kruskal-wallis. Both showed significant result so the analysis continued to post-hoc test. Based on Levene test on oneway ANOVA, data of ethyl acetate extract showed different data variance so they were analysed using Tamhanes. The most significant concentration on ethyl acetate extract were $12,5 \mathrm{ppm}, 400 \mathrm{ppm}$, and $800 \mathrm{ppm}$. Meanwhile, data from ethanol extract were analyzed using Mann- Whitney. It showed that the most significant concentration on ethnol extract was $100 \mathrm{ppm}$.

\section{CONCLUSION}

Ethanol extract of K.rotunda rhizome has strong cytotoxic activity $\left(\mathrm{IC}_{50} 16,939 \mathrm{ppm}\right)$ while ethyl acetate extract of K.rotunda rhizome had moderate cytotoxic activity $\left(\mathrm{IC}_{50} 127,9 \mathrm{ppm}\right.$ ) against HeLa Cell. This showed that ethanol extract of K.rotunda had higher cytoxicitity compared to ethyl acetate extract. Then, both of them have anticancer compounds.

\section{ACKNOWLEDGMENT}

Authors are very grateful to Faculty of Medicine Universitas Indonesia, for PITTA grand and for providing facilities to full fill the work.

\section{CONFLICTS OF INTREST}

The Authors declare no conflicts of interest.

\section{REFERENCES}

1. Andrijono. Pedoman nasional pelayanan kedokteran: kanker serviks. Jakarta: Kemenkes; 2017.
2. Hoffman BL, Schorge JO, Bradshaw KD, Halvorson LM, Schaffer JI, Corton MM. Cervical cancer. In: Hoffman BL, Schorge JO, Bradshaw KD, Halvorson LM, Schaffer JI, Corton MM. Williams gynecology. 3rd ed. US: McGraw-Hill Education; 2016:657-75.

3. Pusat data dan informasi Kemenkes. Infodatin: stop kanker. Jakarta: Kemenkes; 2015:4-5.

4. Nasution RE. Prosiding Seminar dan Loka Karya Nasional Etnobotani. Jakarta: Departement Pendidikan dan Kebudayaan RI LIPI, 2002.

5. Ren W, Qiao Z, Wang H, Zhu L, Zhang L, Zhenhua. Flavonoids: Promising anticancer against, Medicinal Research Reviews. 2003;23(4):519-34.

6. Malahayati N, Widowati TW, Febrianti A. Total phenolic, antioxidant, and antibacterial activities of curcumin extract of kunci pepet (Kaempferia rotunda L.). RJPBCS. 2018;9(3):129-35.

7. Pandey A, Tripathi S. Concept of standardization, extraction, and pre phytochemical screening strategies for herbal drug. J Pharmacogn Phytochem. 2014;2(5):115-9.

8. Malahayati N, Widowati TW, Febrianti A. Total phenolic, antioxidant, and antibacterial activities of curcumin extract of kunci pepet (Kaempferia rotunda L.). RJPBCS. 2018;9(3):129-35.

9. Kumar S, Jyotirmayee K, Sarangi M. Thin layer chromatography: a tool of biotechnology for isolation compounds from medicinal plants. Int J Pharm Sci Rev Res. 2013;18(1):126-32.

10. Bele AA, Khale A. An overview on thin layer chromatography. IJPSR. $2011 ; 2(2): 256-67$.

11. Preethi J, Harita B, Rajesh T. Review on thin layer chromatography. J Formul Sci Bioavailab. 2017; (1):1-4.

12. Kumar A, Kumar S, Navneet. Antimicrobial activity and phytochemical analysis of kaempferia rotunda I. rhizomes. Pharm Lett. 2015;7(9):389-95.

13. Desmiaty Y, Winarti W, Nursih AM, Nisrina H, Finotory G. Antioxidant and antielastase activity of kaempferia rotunda and curcuma zedoaria. Res $J$ Chem Environ. 2018;22(1):95-8.

14. Hariyadi, S. Khasiat Tanaman TOGA untuk Pengobatan Alternatif. Jakarta: Penerbit Kalamedia, 2001

15. Bele AA, Khale A. An overview on thin layer chromatography. IJPSR $2011 ; 2(2): 256-67$.

16. Preethi J, Harita B, Rajesh T. Review on thin layer chromatography. J Formul Sci Bioavailab. 2017;1(1): 1-4.

17. Jo HY. The unreliability of MTT assay in the cytotoxic test of primary cultured glioblastoma cells Exp Neurobiol. 2015;24(3):235-45.

18. Hamilton DF, Ghert M, Simpson AHRW. Interpreting regression models in clinical outcome studies. Bone Joint Res. 2015;4(9):152-3. 


\section{GRAPHICAL ABSTRACT}

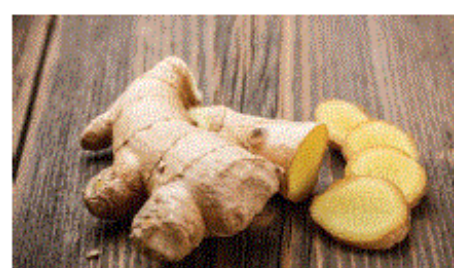

Kaempheria rotunda

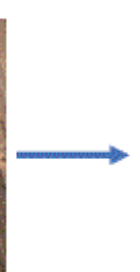

Maceration 48 hours

\section{Ethanol $96 \%$}

Ethyl Acetate

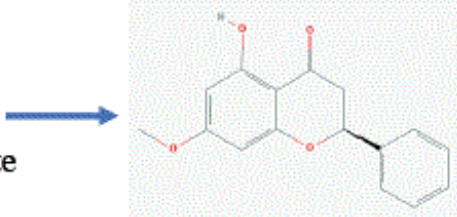

$\mid$

Phytochemical Screening

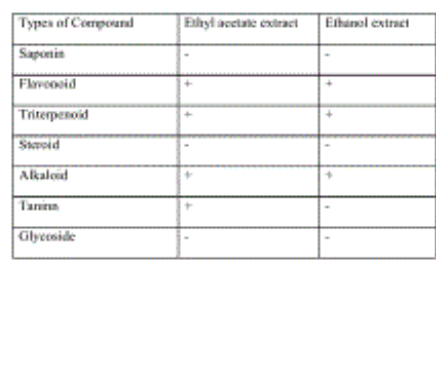

$R f=\frac{\text { Distance traveled by sample (initial line to spot) }}{\text { Distance traveied by solvent in the chamber (initial line to end tine) }}$

Thin Layer Chromatography (TLC)

Ethanol extract $\mathrm{IC}_{50}=16,939 \mu \mathrm{g} / \mathrm{ml}$ Ethyl acetate extract $\mathrm{IC}_{50}=127,9 \mu \mathrm{g} / \mathrm{ml}$

\section{ABOUT AUTHORS}

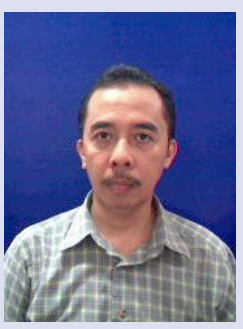

\section{Surya Dwira}

Senior Lecturer at Department of Medical Chemistry, Faculty of Medicine, Universitas Indonesia. Research interest: drug discovery and development from herbal compounds, phytochemical analysis, and analytical chemistry.

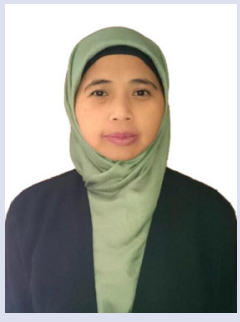

\section{Ariska TP}

Bachelor Student at Faculty of Medicine, Universitas Indonesia. Research interest: drug discovery and development from herbal compounds.

\section{Fadilah}

Senior Lecturer at Department of Medical Chemistry, Faculty of Medicine, Universitas

Indonesia. Research interest: bioinformatics, drug discovery and development from herbal compounds, phytochemical analysis, drug compounds synthesis and molecular modeling. 


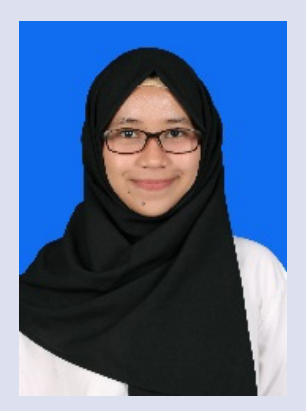

\section{Norma Nur Azizah}

Researcher at Drug Development Research Center (DDRC), Indonesian Medical Education and Research Institute, Faculty of Medicine, Universitas Indonesia. Research interest tissue culture, analytical chemistry and natural product

chemistry in drug development.

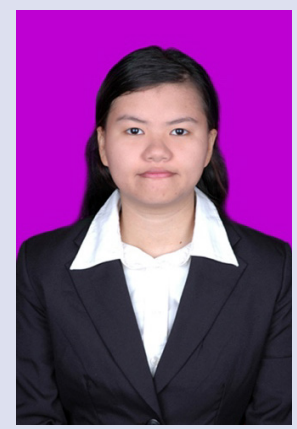

\section{Linda Erlina}

Junior Lecturer at Department of Medical Chemistry, Faculty of Medicine, Universitas

Indonesia. Research interest: drug discovery and development from herbal compounds, bioinformatics and molecular modeling.

Cite this article: Dwira S, Ariska TP, Fadilah F, Azizah NN, Erlina L. Comparison of Cytotoxicity between Ethyl Acetate and Ethanol Extract of White Turmeric (Kaempferia rotunda) Rhizome Extract Against HeLa Cervical Cancer Cell Activity. Pharmacogn J. 2020;12(6):1297-302. 